\title{
Ultrastructural Aspects of Yersinia ruckeri Cells after Treatment with Non-thermal Plasma-activated Water
}

\author{
ANDREI CRISTIAN LUPU ${ }^{1 *}$, ANDRA-CRISTINA BOSTANARU ${ }^{1}$, MIHAI MARES ${ }^{1}$, LAURA URSU², CONSTANTIN ROMAN ${ }^{1}$, \\ RALUCA MINDRU ${ }^{1}$, LIVIU DAN MIRON ${ }^{1}$ \\ University of Agricultural Sciences and Veterinary Medicine Ion Ionescu de la Brad, Faculty of Veterinary Medicine, \\ 8 Al. M. Sadoveanu, 700489, Iasi, Romania \\ IInstitute of Macromolecular Chemistry Petru Poni, Iasi
}

\begin{abstract}
Yersinia ruckeri is the causative agent of enteric red mouth disease (ERM, yersiniosis), one of the most important diseases that affects particularly farmed salmonids species. Numerous articles have demonstrated that Y. ruckeri can cause both epizootics and zoonosis. Y. ruckeri shows the ability to survive outside the host in nutrient-limiting environments for long periods due to biofilms forming capacity with adherence to solid supports but also for the adherence to the host tissues. Considering these aspects, the control of Y. ruckeri can be a problem, because of its resistance. Recently, non-thermal plasma activated water (PAW) proved to be active against Gram-negative bacteria and this fact could be also useful in Y. ruckeri control. The purpose of this in vitro study was to test the antimicrobial efficacy of PAW against Y. ruckeri and to explore the ultrastructural changes in these bacteria. Ultrastructural changes in Y. ruckeri cells, probably related to the action of PAW, included modifications in the shape and texture of the outer membrane. These changes in the bacterial membrane have been linked with the inactivation of bacteria by PAW exposure.
\end{abstract}

Keywords: AFM, plasma activated-water, Yersinia ruckeri

Yersinia ruckeri is a Gram negative, rod shaped bacterium that is able to affect different fish species including carp, trout, catfish, sturgeon, turbot and perch [1]. In salmonids, this bacterium is the causative agent of enteric redmouth disease (ERM) for both fresh and marine waters [2].

Y. ruckeri infections cause high mortality rates in fish farms, especially in rainbow trout (Oncorhynchus mykiss) that leads to significanteconomic losses in the fish farming industries. Although generally w ell controlled by means of vaccination and antibiotic treatment, this disease has kept on causing outbreaks, especially in endemic areas. In these cases, the losses can be as important as $30-70 \%$ of the stock [3]. The Y. ruckeri bacillus is approximately $0.75 \mu \mathrm{m}$ in diameter and 1-3 $\mu \mathrm{m}$ in length and it has a 3.7 Mbp genome, with a $\sim 47 \% \mathrm{G}+\mathrm{C}$ ratio, the same as other Yersinia species [4]. High-throughput DNA sequencing of Yersinia species has confirmed that $Y$. ruckeri shares the same core set of genes with the other members of the genus [5].

$Y$. ruckeri is able to survive for more than four months, especially after an outbreak of the disease [6]. Moreover, the bacterium remains infective in the aquatic environment mainly associated with poor water quality [7] and it has the ability to adhere on solid surfaces and form biofilms [8]. Exceptionally, this microorganism has been isolated from the infected wound of a human, giving it a zoonotic appearance [9].

Non-thermal plasma has recently emerged as a new technique that is used for decontamination of all kind of surfaces being a subject in numerous investigations both in the plasma physics field and medical science [10]. The main advantages of using PAW for bactericidal inhibition include less adverse impact on the environment, and no need for transportation and storage of potentially hazardous chemicals [11]. During this study we have verified the antimicrobial efficacy of the plasma-activated water (PAW) against the bacterium Y. ruckeri.
Taking into account the possibility of using PAW in decontamination and the risk and problems caused by $Y$. ruckeri, the aim of this study is to assess the possibility to use PAW as a sterilizing agent against this microorganism.

\section{Experimental part}

Materials and methods

Plasma-activated water (PAW) was obtained using a GlidArc reactor and $200 \mathrm{~mL}$ of deionized water. Moreover, the plasma generator is supplied by an AC high voltage transformer (output voltage of $10 \mathrm{kV}$ and a maximum output current of $100 \mathrm{~mA}$ ), the gliding arc discharge is running at an industrial frequency of $50 \mathrm{~Hz}$ and uses air as gas carrier at a flow rate of $40 \mathrm{~L} / \mathrm{min}$ [12].

The parameters of the distilled water before activation: conductivity $5 \pm 0.3 \mu \mathrm{S} / \mathrm{cm}, \mathrm{pH} 6.5 \pm 0.16, \mathrm{NO}_{2}$. undetectable, $\mathrm{NO}_{3}$ undetectable and the temperature $20.4 \pm 1.1^{\circ} \mathrm{C}$.

The average value of the power was calculated as 111,8 W. A volume of $250 \mathrm{~mL}$ distilled water was exposed to the plasma for 1, 3, 5, 7 min and then used as contact agent for Yersinia ruckeri. The final physical and chemical parameters of PAW were: conductivity $446 \pm 25 \mu \mathrm{S} / \mathrm{cm}, p \mathrm{H} 2.78 \pm$ $0.12, \mathrm{ORP}+1.06 \mathrm{~V}, \mathrm{NO}-192 \pm 10 \mathrm{mg} / \mathrm{L}, \mathrm{NO}_{3}-1550 \pm 95$ $\mathrm{mg} / \mathrm{L}, \mathrm{H}_{2} \mathrm{O}, 2.6 \pm 0.12 \mathrm{mg} / \mathrm{L}, \mathrm{O}_{3} 1.08 \pm 0.07 \mathrm{mg} / \mathrm{L}$.

The strain of the bacterium used was a RTCC 1877 Yersinia ruckeri. The experiment was performed on Yersinia ruckeri strain subculture into bottles containing Tryptone Soy Broth and cultivated on Muller Hinton agar slants. For the fidelity, and the stability of the experimental results, the tests were repeated multiple times. As inoculum, a bacterial suspension with initial burden of $10^{\circ} \mathrm{CFU} / \mathrm{mL}$ was used. A defined volume of bacterial suspension $(10 \mathrm{~mL})$ with 3 McFarland density (approximately $10^{\circ} \mathrm{CFU} / \mathrm{mL}$ ) was mixed with $90 \mathrm{~mL}$ PAW and after various contact times (1, 3,5 and $7 \mathrm{~min}$ ) known volumes $(0.1$ and $1.0 \mathrm{~mL}$, respectively) were transferred to Plate Count Agar plates 

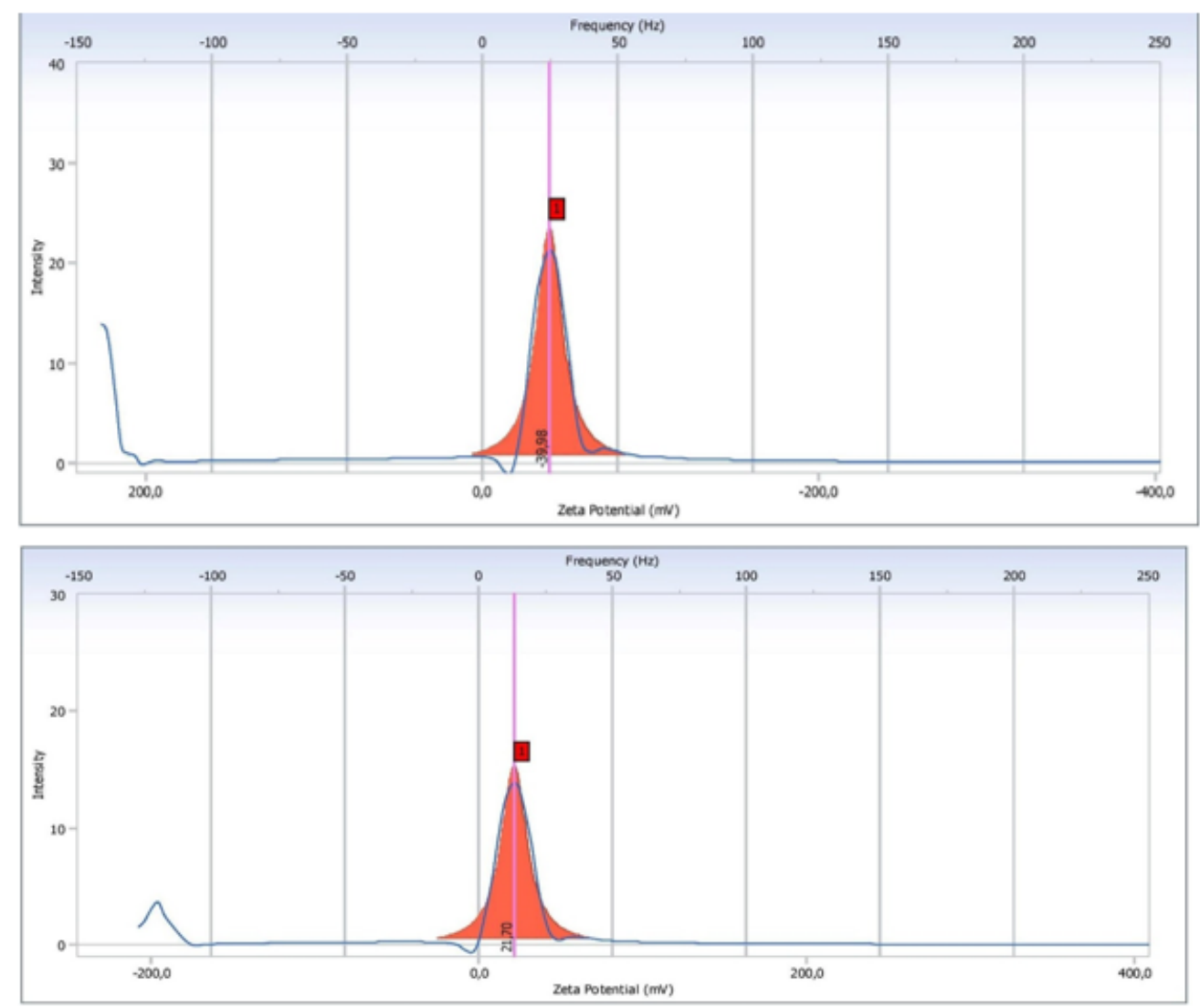

Fig. 1a. Dynamic Light Scattering (DLS) chart before exposure to PAW

Fig. 1b. Dynamic Light Scattering (DLS) chart after exposure to PAW in order to determine the number of $\mathrm{CFU} / \mathrm{ml}$. The plates were incubated at $37^{\circ} \mathrm{C}$ in aerobic conditions for $24 \mathrm{~h}$. The initial concentration of the bacterial suspension determined on Plate Count agar was used as control.

After each contact time, known volumes were transferred onto Löwenstein-J ensen agar in order to evaluate the number of viable bacteria after the PAW treatment.

The reduction of bacterial burden was evaluated using colony-forming unit (CFU) count and the formula: Log Reduction $=\log _{10}$ (CFU before PAW treatment $/$ CFU fatter PAW treatment $)$. Also, the experiment was performed on liquild culture media to demonstrated the effect sterilizing of PAW by incubating the type strains treated with PAW on BacT/ ALERT bottles.

In order to assess the PAW interactions with bacterial cell wall Dynamic Light Scattering (DLS) and Atomic Force Microscopy (AFM) was used. Zeta potential of the particles were examined on the Delsa Nano Submicron Particle Size Analyzer (Beckman Colter) that uses electrophoretic light scattering (ELS) for zeta potential determination.

To image bacteria by AFM, the same volume of bacteria suspension was deposited on glass cover slips and dried in air at room temperature. AFM images were recorded using an Ntegra Spectra instrument (NT-MDT, Russia) operated in tapping mode under ambient conditions. Silicon cantilever tips (NSG 10) with a resonance frequency of 140-390 kHz, a force constant of 5.5-22.5 N m$~_{-1}$ and tip curvature radius of $10 \mathrm{~nm}$ were used.

\section{Results and discussions}

The experimentwas performed on Yersinia ruckeri RTCC 1877 strain. PAW was obtained in a GlidArc reactor.

In order to assess the impact of PAW interaction with bacterial cell wall Dynamic Light Scattering (DLS) and Atomic Force Microscopy (AFM) were used.
Dynamic Light Scattering (DLS) method was used for the Zeta potential assessment. Zeta potential measurements can be used to assess the bacterial surface charge. It is actually a charge on a particle at the shear plane. This value of the surface charge is important for understanding and predicting interactions between particles in suspension. Surface neutralizations of the cell membrane are important for the antimicrobial activity of PAW, which properly acts on the bacterial surface. Timing measurements for the treatmentexposure were performed after 1,3,5,7 min of contact with the bacterial suspension of Yersinia. ruckeri. All measurements were done in triplicates. Any positive value on the chart indicates nonviable bacteria (fig. 1 and 2). The zeta potential value strongly correlates with bacteria inactivation (negative cultures) $-p<0.01$.

\section{Conclusions}

The interaction with PAW agent with the cell surface may involve some mechanisms, interactions with different functional radicals or groups with bacterial surface, resulting in the perturbation of the membrane integrity. This action basically leads to an increase in the cell permeability, which may ultimately result in cell death. Ultrastructural changes in the $Y$. ruckericells were probably related to the action of PAW. These changes included modifications in the shape and texture of the outer membrane as shown in the figure 3. Before the treatment of Y. ruckeri with PAW, the outer surface of the cell was rough, with prominent ridges, but following exposure to PAW, the surface has changed and appeared smoother showing that the periplasmic space has greatly increased after the treatment. Ultrastructural changes in the bacterial membrane mean that the bacteria has been killed by PAW.

The logarithmic reduction was higher than $5 \log _{10}$ after an exposure time of $2 \mathrm{~min}$ proving a powerful bactericidal effect confirmed by positive values of Zeta potential. This 

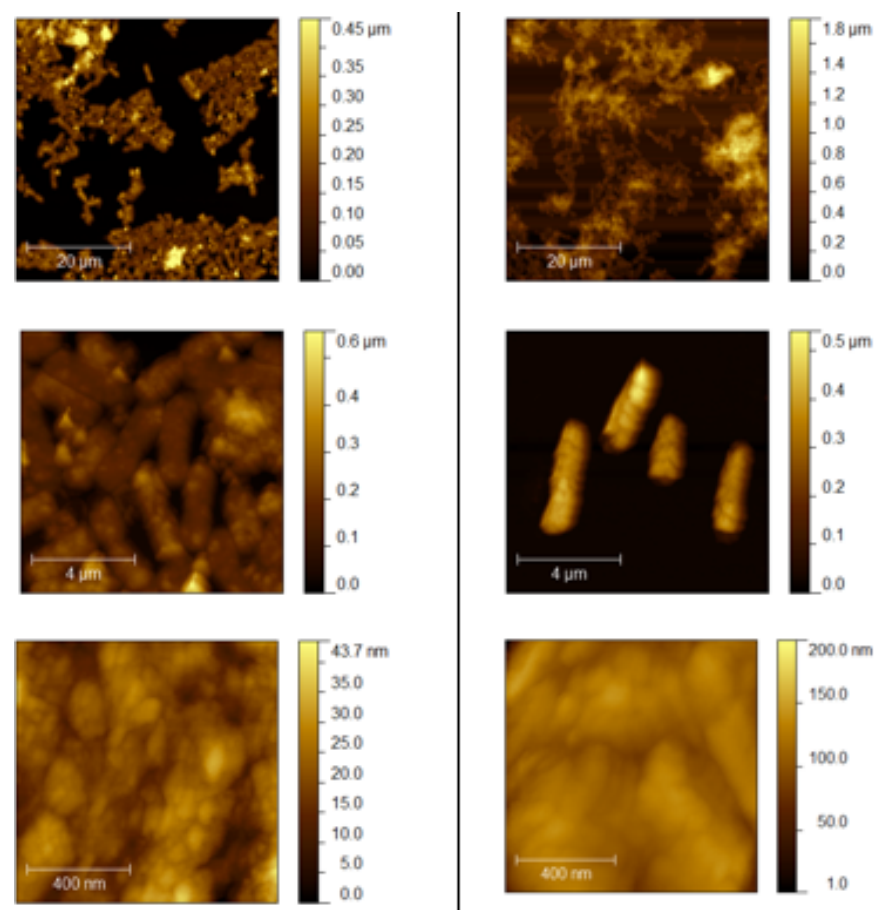

Fig. 3. Atomic Force Microscopy (AFM) analysis A) Before exposure to PAW and B) After exposure to PAW

concludes that PAW could be a powerful sterilizing agent for neutralization for the pathogen Yersinia ruckeri.

\section{References}

1.DESIREE, C., JOSE A., ANA I. G., JESSICA M., Microbiology, 2017.

2.KUMAR, G., HUMMEL, K., WELCH, T.J ., RAZZAZI-FAZELI, E., ELMATBOULI M., Veterinary Research 2017, 48:55.
3.FERNANDEZ, L., MENDEZ, J., GUIJARRO, J.A., Vet Microbiol 2007; 125:1-10

4.GOKHLESH, K., MENANTEAU-LEDOUBLE, S., SALEH, M., ELMATBOULI, M., Veterinary Research (2015) 46:103.

5.CHEN, P.E., COOK, C., STEWART, A.C., NAGARAJAN, N., SOMMER, D.D., POP M., THOMASON, B., THOMASON, M.P., LENTZ, S., NOLAN, N., SOZHAMANNAN, S., SULAKVELIDZE, A., MATECZUN, A., DU L., ZWICK M.E., Read TD Genomic characterization of the Yersinia genus. Genome Biol 11:R1(2010)

6.THORSEN, B.K., ENGER O., NORLAND S., HOFF K.A. Appl Environ Microbiol 1992; 58:1624 - 1628.

7.WANGER A., Topleyand Wilson's microbiology and microbial infections: bacteriology. Washington, DC: ASM Press, 2005; 14581473.

8.COQUET, L., COSETTE, P., QUILLET L., PETIT F., JUNTER G.A., JOUENNE T., Appl Environ Microbiol 2002; 68: 470-475

9.S. DE KEUKELEIRE, A. DE BEL, Y. J ANSEN, M. J ANSSENS, G.WAUTERS, D. PIERARD, Yersinia ruckeri, an unusual microorganism isolated from a human wound infection , Fish \& Shellfish Immunology, 2010, 648-655.

10.URSACHE, M., MORARU, R., HNATIUC, E., NASTASA, V., MARES, M., IEEE 2014, pp. 1036-1041.

11.SHEN, J., TIAN, Y., LI, Y., MA, R., ZHANG, Q., ZHANG J ., FANG J ., Scientific Reports vol 6, doi:10.1038/srep28505, article number: 28505, 2016.

12.PASCA, S., NASTASA, V., BOSTANARU, A.C., MARESM., - DOI: 10.1109/ OPTIM.2017.7975114, IEEE 2017.

$\overline{\text { Manuscript received: } 14.08 .2018}$ 